\title{
Current and future prospects in the management of granulomatosis with polyangiitis (Wegener's granulomatosis)
}

This article was published in the following Dove Press journal:

Therapeutics and Clinical Risk Management

17 April 2014

Number of times this article has been viewed

\section{Ruth M Tarzi \\ Charles D Pusey}

Renal and Vascular Inflammation Section, Department of Medicine, Imperial College, London, UK
Correspondence: Ruth Tarzi Renal and Vascular Inflammation Section, Department of Medicine, 5th Floor Commonwealth Building, Hammersmith Campus, Imperial College London, Du Cane Rd, London WI2 ONN, UK

Email r.tarzi@imperial.ac.uk
Abstract: Granulomatosis with polyangiitis (GPA, formerly Wegener's granulomatosis) is a multisystem autoimmune condition associated with anti-neutrophil cytoplasm antibodies. Management of GPA can be complex, owing to the sometimes fulminant and multisystem nature of the presentation, the age demographics of the affected population, and a significant incidence of disease relapse. In this paper, we discuss how some of the challenges in the management of GPA have been and continue to be addressed including: reducing the toxicity of induction therapy; developing biomarkers to determine who can safely stop maintenance immunosuppression; improving the efficacy of maintenance therapy for relapsing patients; managing localized disease; and management of disease and treatment-associated comorbidity. Consideration is also given to emerging therapeutics in the treatment of GPA.

Keywords: anti-neutrophil cytoplasm antibody, vasculitis, immunosuppression, biologics

\section{Introduction}

Granulomatosis with polyangiitis (GPA, formerly known as Wegener's granulomatosis) is one of the anti-neutrophil cytoplasm antibody (ANCA)-associated small vessel vasculitides (AAV). ${ }^{1}$ The other clinical syndromes associated with ANCA are microscopic polyangiitis (MPA) and eosinophilic granulomatosis with polyangiitis (formerly known as Churg Strauss syndrome). ${ }^{2}$ Characteristic pathological features of GPA include arteritis of small-sized to medium-sized blood vessels, and granulomatous inflammation of the upper airways and lungs. ${ }^{1}$ Renal involvement with a pauci-immune necrotizing glomerulonephritis is one of the commonest severe manifestations, occurring in $75 \%$ of patients during the course of the disease, ${ }^{3,4}$ and AAV is the commonest cause of a pulmonary-renal syndrome presenting with acute renal dysfunction and pulmonary hemorrhage. ${ }^{5} \mathrm{AAV}$ are rare diseases with a combined incidence of 20 per million per year and a prevalence of 144 per million in the UK. ${ }^{6}$ Two thirds of cases of AAV in the UK are GPA. ${ }^{6}$ AAV can occur at any age, including childhood, but is most common in older patients (peak age 55-70 years), and occurs equally in both sexes. ${ }^{6} \mathrm{AAV}$ causes significant morbidity and mortality, with end-stage renal failure occurring in more than $20 \%$ of patients at 5 years and a 5 -year survival rate of approximately $75 \%{ }^{7,8}$ Prompt diagnosis and treatment is important to avoid mortality and/or permanent organ damage. With treatment, $85 \%-90 \%$ of patients will go into remission, ${ }^{9}$ but the disease follows a relapsing-remitting course, with a $50 \%$ relapse rate within 5 years. ${ }^{10}$ This review focuses on challenges in the management of GPA. In order to set the context for this, we first give a brief overview of the pathogenesis and clinical features of GPA 
in the context of AAV as a whole. More detailed information on these aspects can be obtained from other recent reviews. ${ }^{11,12}$

\section{Pathogenesis of AAV}

ANCA are directed against glycoprotein enzymes present in neutrophil granules and monocyte lysosomes, most notably proteinase 3 (PR3) ${ }^{13}$ and myeloperoxidase (MPO). ${ }^{14}$ Cytokine-primed neutrophils and monocytes express the target antigens on their surface. ${ }^{15}$ Binding of ANCA to these antigens activates the cells, leading to a superoxide burst, and release of lytic enzymes and proinflammatory cytokines such as interleukin (IL)-8. ${ }^{16-18}$ ANCA binding to neutrophils promotes endothelial adhesion and cytotoxicity to cultured endothelial cells. ${ }^{18,19}$ There is in vivo evidence for the direct pathogenicity of MPO-ANCA from maternal-fetal transfer and from mouse and rat models. ${ }^{20-22}$ PR3 does not have a direct murine homolog, but immunoglobulin from PR3-ANCA-positive patients caused glomerulonephritis in a humanized mouse model. ${ }^{23} \mathrm{~T}$ cells are also important, because effector memory $\mathrm{T}$ cells are present in chronic vasculitic lesions in GPA $^{24,25}$ and antigen-specific Th17 cells, and the cytokines IL-17 and IL-23 were raised in patients with active $\mathrm{AAV}^{26}$ There is recent evidence of defective $\mathrm{T}$ and $\mathrm{B}$ cell regulation in AAV. ${ }^{27-30}$ Emerging data suggest that activation of the alternative pathway of complement is important in AAV, and may be a therapeutic target. ${ }^{31-33}$

\section{Genetics of AAV}

A genome-wide association study (GWAS) has confirmed that GPA and MPA are different diseases with different major histocompatibility complex associations. ${ }^{34}$ In the GWAS, GPA was also associated with the gene for its autoantigen PR3, confirming the importance of this antigen in the pathogenesis of the disease. The genetic associations were stronger for PR3-ANCA and MPO-ANCA rather than for the clinical syndromes of GPA and MPA, prompting consideration of whether these biomarkers should be used to stratify patients. ${ }^{35}$

\section{Clinical features of GPA}

Systemic GPA often presents with symptoms of weight loss, fever, fatigue, arthralgia, and myalgia., ${ }^{3,4}$ GPA is characterized by granulomatous upper airways involvement in about $90 \%$ of patients. ${ }^{3}$ Upper respiratory tract symptoms include epistaxis, sinusitis, otitis media, deafness, hoarseness, stridor, and proptosis due to orbital involvement. The granulomatous inflammation can lead to local damage, including nasal septal perforation, saddle nose, and tracheal stenosis. ${ }^{36}$ Lung involvement occurs in $85 \%$ of patients with GPA at some stage, and includes pulmonary nodules and cavities, pulmonary infiltrates, pleural effusion, and pulmonary fibrosis. ${ }^{3}$ Alveolar hemorrhage occurs in approximately $20 \%$ of patients with active GPA. ${ }^{37}$ Renal involvement is a common feature of GPA, with necrotizing and crescentic glomerulonephritis occurring in 75\% of patients at some point in their disease. ${ }^{3}$ Renal replacement therapy is required in $20 \%-30 \%$ of patients, either due to rapidly progressive glomerulonephritis, or to gradual loss of kidney function over time. ${ }^{7}$ Almost any organ in the body can be involved, but in particular vasculitic skin lesions, peripheral neuropathy, mononeuritis multiplex, granulomatous meningeal involvement, cardiac disease, and gut involvement are well recognized in GPA. ${ }^{3}$ Localized GPA refers to granulomatous vasculitis limited to the upper airways, sinuses and orbits, or lungs, without systemic involvement or constitutional symptoms, and occurs in about $5 \%$ of patients with GPA. ${ }^{38,39}$ However, as stated above, about $90 \%$ of patients with systemic GPA have granulomatous disease of the upper airways. ${ }^{3}$ Localized GPA has a high propensity for relapse, ${ }^{40}$ and can cause significant local damage over time,${ }^{36}$ as well as treatment-associated morbidity if recurrent courses of induction treatment are required.

By contrast, MPA is characterized by systemic vasculitis without granulomatous disease. Pauci-immune glomerulonephritis is very common in MPA ${ }^{4}$ however, upper airways granulomata and pulmonary nodules are not a feature, and chronic lung damage in MPA tends to present with a more fibrosing, restrictive pattern. ${ }^{41}$ Pulmonary hemorrhage can occur in both active GPA and active MPA. ${ }^{37}$

\section{Relapse risk in GPA}

The relapse risk of GPA is approximately $50 \%$ at 5 years. ${ }^{10}$ GPA and PR3-ANCA-positive patients are significantly more likely to relapse than patients with MPO-ANCA or MPA. ${ }^{40,42,43}$ Patients with granulomatous disease of the upper airways are also more likely to relapse than those without this manifestation, whilst those with renal impairment had a reduced relapse risk. $^{40,43}$ A rise in ANCA titer is not strongly predictive of relapse at an individual patient level, so it is important to monitor clinical symptoms and signs, as well as inflammatory markers. ${ }^{44}$ More information about predicting relapse in GPA is discussed in the section on management below.

\section{Laboratory markers of GPA}

PR3-ANCA has a high sensitivity and specificity for the diagnosis of active GPA ( $>90 \%)$, in the right clinical context, although ANCA-negative and MPO-ANCA-positive cases 
do occur. ${ }^{45}$ However, $50 \%$ of patients with the clinical syndrome of localized GPA are ANCA-negative. ${ }^{38}$ Inflammatory markers such as erythrocyte sedimentation rate and C-reactive protein are also usually raised in active AAV. The gold standard for diagnosis of AAV is the finding of small vessel vasculitis on biopsy. The kidney is usually the best site for diagnosis, where a pauci-immune necrotizing glomerulonephritis is seen. In GPA, granulomatous inflammation is present in the upper airways, but in practice this is often missed in small biopsies due to sampling errors, and nonspecific collections of inflammatory cells are often found in biopsies of the lung or upper airways.

\section{Efficacy and side effects of current and historical management strategies}

In the 1950s, the prognosis of generalized GPA was poor, with only about $10 \%$ survival at 2 years. ${ }^{46}$ In the 1970 s, a regimen of cyclophosphamide and glucocorticoids was introduced at the National Institutes of Health, leading to remission in $85 \%-90 \%$ of patients within 3-6 months, but high cumulative toxicity of cyclophosphamide. ${ }^{46}$ Improvements in supportive management, including the availability of hemodialysis for renal failure and ventilatory support for pulmonary hemorrhage have also improved the prognosis of severe vasculitis. However, high cumulative doses of cyclophosphamide have been associated with a number of short-term and long-term side effects, including infections, leukopenia, impaired fertility, and cancer. ${ }^{47-51}$ Corticosteroids also have a number of well documented side effects, including weight gain, diabetes, osteoporosis, increased cardiovascular risk, psychological effects, and skin thinning. Studies have shown that there is a greater chance of death from infection than from uncontrolled disease within the first year of diagnosis of $\mathrm{AAV}^{52}$

\section{Aims of treatment of GPA}

AAV are believed to be autoimmune diseases and are treated by immunosuppression. Treatment of AAV is divided into two phases, ie, an induction phase and a remission maintenance phase. The aim of induction treatment is to rapidly reduce inflammation to control signs and symptoms of disease and prevent permanent tissue damage. In the remission maintenance phase, lower-dose immunosuppression is used to prevent relapse. Of course, these aims should be achieved with the minimum of toxicity. As a guide, Table 1 lists the induction and maintenance strategies that are commonly in use for different severities of GPA, with reference to the evidence supporting them. Table 2 lists the short-term and long-term side effects that have been associated with the drugs most commonly used to
Table I Evidence for immunosuppression in GPA, based on disease severity

\begin{tabular}{|c|c|c|}
\hline $\begin{array}{l}\text { Clinical } \\
\text { phenotype }\end{array}$ & $\begin{array}{l}\text { Immunosuppressive } \\
\text { (plus corticosteroids) }\end{array}$ & Evidence \\
\hline Early systemic & $\begin{array}{l}\text { Methotrexate (minor disease } \\
\text { only), or cyclophosphamide or } \\
\text { rituximab, plus cotrimoxazole if } \\
\text { nasal involvement }\end{array}$ & $\begin{array}{l}\text { NORAM }^{59,60} \\
\text { RAVE }^{62,64} \\
\text { Cotrimoxazole }\end{array}$ \\
\hline Generalized & Cyclophosphamide or rituximab & $\begin{array}{l}\text { CYCAZAREM }^{56} \\
\text { CYCLOPS }^{57,58} \\
\text { RAVE }^{62,64} \\
\text { RITUXVAS }^{63}\end{array}$ \\
\hline Severe & $\begin{array}{l}\text { Cyclophosphamide or } \\
\text { rituximab (given with } 2 \text { doses } \\
\text { of cyclophosphamide in } \\
\text { RITUXVAS trial) plus plasma } \\
\text { exchange }\end{array}$ & $\begin{array}{l}\text { RITUXVAS }^{63} \\
\text { MEPEX }^{69,70}\end{array}$ \\
\hline Major relapse & $\begin{array}{l}\text { Cyclophosphamide or rituximab } \\
\text { (rituximab more effective in } \\
\text { RAVE trial) }\end{array}$ & RAVE $^{62,64}$ \\
\hline \multirow[t]{3}{*}{ disease } & $\begin{array}{l}\text { Rituximab } \\
\text { Intravenous immunoglobulin }\end{array}$ & $\begin{array}{l}\text { Roll et } \mathrm{al}^{73} \\
\text { Jayne et } \mathrm{al}^{74} \\
\text { Martinez et } \mathrm{al}^{75}\end{array}$ \\
\hline & Infliximab & $\begin{array}{l}\text { Booth et } \mathrm{al}^{78} ; \\
\text { Lamprecht et al }{ }^{127}\end{array}$ \\
\hline & $\begin{array}{l}\text { Alemtuzumab } \\
\text { Mycophenolate mofetil } \\
\text { I5-deoxyspergualin }\end{array}$ & $\begin{array}{l}\text { Walsh et } \mathrm{al}^{76} \\
\text { Joy et al }{ }^{79} \\
\text { Birck et al }{ }^{77}\end{array}$ \\
\hline $\begin{array}{l}\text { Maintenance } \\
\text { therapy }\end{array}$ & $\begin{array}{l}\text { Azathioprine or methotrexate } \\
\text { (or rituximab - currently under } \\
\text { evaluation) }\end{array}$ & $\begin{array}{l}\text { CYCAZAREM }^{56} \\
\text { IMPROVE }^{84} \\
\text { WEGENTT }^{85}\end{array}$ \\
\hline & mycophenolate mofetil, leflunomide & German Network \\
\hline & & $\begin{array}{l}\text { Study }{ }^{87} \\
\text { MAINRITSAN }{ }^{90}\end{array}$ \\
\hline
\end{tabular}

Abbreviations: GPA, granulomatosis with polyangitis; CYCAZAREM, Cyclophosphamide vs azathioprine for early remission phase of vasculitis; CYCLOPS, Randomized trial of daily oral versus pulse cyclophosphamide as therapy for ANCA-associated systemic vasculitis; MEPEX, Methylprednisolone versus Plasma Exchange; NORAM, Nonrenal Wegener's Granulomatosis Treated Alternatively with Methotrexate; RAVE, Rituximab in ANCA-Associated Vasculitis; RITUXVAS, Rituximab Versus Cyclophosphamide in ANCA-Associated Vasculitis;ANCA, anti-neutrophil cytoplasm antibody; MAINRITSAN, Efficacy Study of Two Treatments in the Remission of Vasculitis; WEGENT, Wegener's Granulomatosis-Entretien/Maintenance; ANCA, anti-neutrophil cytoplasm antibody; IMPROVE, International Mycophenolate Mofetil Protocol to Reduce Outbreaks of Vasculitides.

treat GPA. In this review, we have chosen to discuss particular challenges in managing GPA, namely: reducing the toxicity of induction therapy for GPA; the development of predictive tools to determine who can safely stop maintenance immunosuppression; improving the efficacy of remission maintenance strategies in GPA; managing localized GPA; and management of disease and treatment-related comorbidity. Finally, we discuss the possible future therapeutics in the management of AAV.

The results of randomized trials of induction therapy for AAV discussed below have enabled a reduction in the intensity and duration of induction immunosuppression for GPA, and evidence would suggest that this has led to improvements in outcome over the past 30 years. ${ }^{53,54}$ Several of the trials have been 
Table 2 Short-term side effects and long-term damage associated with treatment in GPA

\begin{tabular}{|c|c|c|}
\hline Drug & Short-term side effects & $\begin{array}{l}\text { Long-term damage (\% affected at } \\
\text { long-term follow-up) }\end{array}$ \\
\hline Corticosteroids & $\begin{array}{l}\text { Weight gain } \\
\text { Skin thinning } \\
\text { Purpura } \\
\text { Striae } \\
\text { Muscle weakness } \\
\text { Diabetes } \\
\text { Insomnia } \\
\text { Mood disturbance } \\
\text { Psychosis } \\
\text { Bacterial infection }\end{array}$ & $\begin{array}{l}\text { Hypertension, } 41.5 \% * \\
\text { Osteoporosis, } 14.1 \% * \\
\text { Avascular necrosis, } 0.7 \% * \\
\text { Cataract, } 9.3 \% * \\
\text { Angina/CABG, } 8.1 \% * \\
\text { Stroke, } 3.7 \% * \\
\text { Muscle atrophy, } 7.4 \% *\end{array}$ \\
\hline Cyclophosphamide & $\begin{array}{l}\text { Neutropenia } \\
\text { Lymphopenia } \\
\text { Bacterial infection } \\
\text { Pneumocystis jirovecii pneumonia } \\
\text { Hemorrhagic cystitis } \\
\text { Teratogenicity }\end{array}$ & $\begin{array}{l}\text { Gonadal failure, } 4.1 \% * \\
\text { Bone marrow failure, } 3 \%^{*} \\
\text { Hypogammaglobulinemia }^{128} \\
\text { Bladder cancer (SIR } 2.4)^{47} \\
\text { Myeloid leukemia (SIR } 3.2)^{47} \\
\text { Nonmelanoma skin cancer (SIR 2.8) }\end{array}$ \\
\hline Rituximab & $\begin{array}{l}\text { Infection } \\
\text { Allergic reactions } \\
\text { Reactivation of hepatitis B (check status } \\
\text { before starting) }\end{array}$ & $\begin{array}{l}\text { Progressive multifocal } \\
\text { leukoencephalopathy (rare }<1: 10,000)^{92} \\
\text { Hypogammaglobulinemia (repeated doses } \\
\text { or prior immunosuppression) }{ }^{128}\end{array}$ \\
\hline $\begin{array}{l}\text { Azathioprine (check TPMT before } \\
\text { starting) }\end{array}$ & $\begin{array}{l}\text { Lymphopenia } \\
\text { Liver blood test abnormalities } \\
\text { Rash } \\
\text { Infection }\end{array}$ & $\begin{array}{l}\text { Associated with nonmelanoma skin } \\
\text { cancer }^{108,109}\end{array}$ \\
\hline $\begin{array}{l}\text { Methotrexate (avoid if eGFR }<30 \mathrm{~mL} \\
\text { per minute) }\end{array}$ & $\begin{array}{l}\text { Nausea/gastrointestinal side effects } \\
\text { Abnormal liver blood tests } \\
\text { Macrocytosis } \\
\text { Leukopenia } \\
\text { Infection } \\
\text { Teratogenicity }\end{array}$ & $\begin{array}{l}\text { Lung injury }(<1 \%)^{129} \\
\text { Liver injury (unusual if liver tests } \\
\text { monitored and action taken if abnormal) }\end{array}$ \\
\hline Mycophenolate mofetil & $\begin{array}{l}\text { Gastrointestinal upset } \\
\text { Leukopenia } \\
\text { Infection } \\
\text { Teratogenicity }\end{array}$ & $\begin{array}{l}\text { Not clear whether risk of skin or } \\
\text { lymphoproliferative malignancy increased }\end{array}$ \\
\hline
\end{tabular}

Note: *Evidence from the European Vasculitis Study Group trial data. ${ }^{48}$

Abbreviations: CABG, coronary artery bypass grafting; eGFR, estimated glomerular filtration rate; GPA, granulomatosis with polyangiitis; SIR, standardized incidence ratio; TPMT, thiopurine methyltransferase.

carried out by the European Vasculitis Study Group (EUVAS). In their trials, EUVAS decided to subgroup vasculitis according to severity, to give high-intensity treatment to induce remission and low-intensity immunosuppression to prevent relapse, to agree on a standard regimen by consensus, to test against current best practice by randomized controlled trials, and to use standardized scoring systems for measuring outcome.

\section{Reducing the toxicity of induction therapy for GPA}

Induction therapy for GPA is effective for most patients, but the toxicity can be high, especially in elderly patients and those with severe renal impairment. ${ }^{55}$ The two main approaches to reduce toxicity have been to reduce the cyclophosphamide exposure, and more recently, trials have been designed to reduce exposure to corticosteroids. Table 3 lists the randomized controlled trials of induction therapy that have been carried out in AAV over the past 20 years and summarizes their main outcomes, and Table 4 lists the induction trials currently ongoing or completed and not yet published. Most of these trials included patients with either GPA or MPA.

\section{Reducing the doses of cyclophosphamide}

The CYCAZAREM (Cyclophosphamide vs azathioprine for early remission phase of vasculitis) study established that it was possible to switch from cyclophosphamide to azathioprine once remission was attained at 3-6 months, thereby reducing cyclophosphamide exposure. ${ }^{56}$ The CYCLOPS (Randomized trial of daily oral versus pulse cyclophosphamide as therapy for ANCA-associated systemic vasculitis) trial showed that 
was no difference in mortality or renal function at the end of the study. ${ }^{58}$ Due to the toxicity of cyclophosphamide, lowerdose therapy is generally preferred.

\section{Assessing alternatives to cyclophosphamide}

The NORAM (Nonrenal Wegener's Granulomatosis Treated Alternatively with Methotrexate) study demonstrated that methotrexate was as effective as cyclophosphamide in inducing remission in early systemic AAV, but in the longer term, disease control was less effective in the methotrexate arm. ${ }^{59,60}$ Therefore, methotrexate induction is usually reserved for patients with localized or early systemic disease without major tissue destruction, although it is used more commonly to maintain remission.

Mycophenolate mofetil (MMF) 2-3 g/day has been compared with intravenous cyclophosphamide for induction therapy in AAV in MYCYC (A randomized clinical trial of mycophenolate mofetil versus cyclophosphamide for remission induction in ANCA-associated vasculitis) and presented in abstract form. ${ }^{61}$ The primary endpoint was remission whilst adhering to the glucocorticoid regimen, and this occurred in 46/70 of the MMF group compared with 48/70 of the intravenous cyclophosphamide group. This study just failed to demonstrate the noninferiority for MMF, but the secondary endpoint of remission irrespective of steroid compliance was achieved. However, unpublished data would suggest that the relapse rate was higher in the MMF group and further details are awaited.

Targeting B cells with rituximab in combination with corticosteroids has proven to be noninferior to cyclophosphamide and corticosteroids followed by azathioprine for inducing remission in AAV, as demonstrated in the RAVE (Rituximab in ANCA-Associated Vasculitis) and RITUXVAS (Rituximab Versus Cyclophosphamide in ANCA-Associated Vasculitis) studies. ${ }^{62,63}$ In the RAVE study, rituximab was more effective than cyclophosphamide in achieving remission in the subgroup of patients with relapsing disease. ${ }^{62,64}$ Rituximab is a chimeric monoclonal antibody binding to CD20, an antigen expressed on the surface of B cells, leading to a reduction in the numbers of circulating $\mathrm{B}$ cells for a variable period of 4-12 months. B cells are the precursors of ANCproducing plasma cells, and in addition, PR3-specific affinitymatured B cells were found in nasal biopsy specimens from patients with active GPA. ${ }^{65}$ Rituximab is not known to reduce fertility or to promote cancer, so this treatment has provided an important additional option for induction therapy of AAV, and may also enable patients with relapsing disease to avoid high cumulative doses of cyclophosphamide.

\section{Reducing corticosteroid exposure during induction treatment}

For systemic GPA, high-dose corticosteroids are used as part of the induction regimen, initially at $1 \mathrm{mg} / \mathrm{kg}$ up to $60 \mathrm{mg} /$ day. These are weaned down over several weeks to a dose of 10 $\mathrm{mg}$ daily after around 3 months or once remission is attained. High-dose corticosteroids are associated with a number of short-term and long-term side effects (Table 2). Infections are the commonest cause of death in the first year after the diagnosis of AAV. ${ }^{52}$ Substitution of rituximab for cyclophosphamide failed to reduce the early adverse event rates in the RAVE and RITUXVAS trials, including infections. ${ }^{62,63}$ This disappointing result tends to implicate high-dose corticosteroids, used as part of the induction regimen, in the infection rate. The RAVE and RITUXVAS trials both used intravenous methylprednisolone at induction, which may have contributed to the adverse event rate. Minimization of steroid exposure is a key target for future trials. PEXIVAS [An International Randomized Controlled Clinical Trial Assessing Plasma Exchange and Steroid Dosing in the Treatment of Severe Anti-Neutrophil Cytoplasm Antibody (ANCA) Associated Vasculitis] is examining the effect of more rapid weaning of steroids on the outcomes in patients with AAV. ${ }^{66}$ The CLEAR (C5aR inhibitor on Leukocytes Exploratory ANCA-associated Renal Vasculitis) study is examining whether a $\mathrm{C} 5 \mathrm{a}$ receptor antagonist (CCX168) can reduce or eliminate the need for oral corticosteroids in induction therapy for $\mathrm{AAV}^{67}$

\section{Management of severe and refractory GPA}

Plasma exchange is recommended for patients presenting with AAV with severe renal inflammation causing acute renal dysfunction. The rationale is for rapid removal of ANCA, and possibly other inflammatory mediators, before immunomodulatory and anti-inflammatory drugs have had an impact. ${ }^{68}$ The MEPEX (Methylprednisolone versus Plasma Exchange) trial was designed to assess renal recovery in patients with AAV and serum creatinine $>500 \mu \mathrm{mol} / \mathrm{L}$. ${ }^{69}$ Although benefit from plasma exchange in terms of renal recovery was achieved, longer-term follow-up demonstrated no difference in long-term mortality. ${ }^{70}$ This uncertainty led to the design of the PEXIVAS trial, recruiting a larger number of patients $(n=500)$ and including those with pulmonary hemorrhage. Hopefully, this study will answer the question of whether plasma exchange is indicated in severe renal AAV more definitively, and also determine the utility of plasma exchange in pulmonary hemorrhage and lesser degrees of renal impairment. ${ }^{66}$ 
Approximately $5 \%$ of patients with GPA fail to go into remission after induction therapy, and are termed refractory. ${ }^{71,72}$ This group of patients is particularly difficult to manage. The German Registry of Autoimmune Diseases published an analysis of the responses of patients with AAV (50/58 with GPA) refractory to rituximab. Forty percent were classified as complete responders, and a further $52.7 \%$ demonstrated a partial response, indicating that rituximab should be considered as first-line therapy in patients not responding to cyclophosphamide induction. ${ }^{73}$ Open-label studies suggest a number of options for patients not responding to cyclophosphamide or rituximab, ie, alemtuzumab (anti-CD52), tumor necrosis factor (TNF) antagonists, mycophenolate mofetil, 15-deoxyspergualin (an antiproliferative agent targeting antigen-stimulated B cells), or intravenous immunoglobulin. ${ }^{72,74-79}$ Intravenous immunoglobulin can be helpful as an option in patients with active infection or those who have not tolerated immunosuppression, although frequent retreatment may be required..$^{74,75}$

\section{Predictive tools to determine who can safely stop maintenance immunosuppression}

Disease relapse remains a problem in GPA, with a $50 \%$ relapse rate over the course of 5 years. ${ }^{3}$ Minor relapses may be managed with an increase in oral glucocorticoids or optimization of maintenance immunosuppression dosing, but major relapses require repeated induction therapy. The risk of relapse of GPA and PR3-ANCA-positive vasculitis is higher than for other forms of vasculitis such as MPA, and previous relapse is also predictive of future flares..$^{10,43,64}$ Lung and upper airways involvement in GPA are associated with higher relapse rates. ${ }^{10}$ Reduced intensity induction therapy ${ }^{42,59}$ or early withdrawal of immunosuppression or glucocorticoids ${ }^{80}$ has been associated with an increased risk of relapse. However, although risk factors of relapse can be defined at a population level, we are unable to predict with any great degree of certainty the outcome for any one particular patient with GPA. Therefore, close clinical monitoring of symptoms, signs, and inflammatory markers is required to detect relapses at an early stage, and it is likely that many patients are immunosuppressed for longer than necessary, due to uncertainty about their risk of relapse. ANCA positivity is a good diagnostic marker for GPA. ${ }^{45}$ However, a meta-analysis of available studies showed that a rise in ANCA titers during remission was only weakly associated with relapse, and therefore not very useful for predicting the disease course in individual patients. ${ }^{44}$ It is our practice not to modify treatment based on changes in ANCA status alone, but to monitor patients with rising ANCA titers carefully for clinical signs of relapse, along with monitoring inflammatory markers such as $\mathrm{C}$-reactive protein. There is a need for more reliable biomarkers to predict relapse in $\mathrm{AAV}$ patients.

McKinney et al have discovered a CD8 T cell messenger RNA signature detectable at diagnosis, which was associated with relapse in patients with $\mathrm{AAV}$ and a range of autoimmune conditions. ${ }^{81}$ This signature was only discernible in isolated leukocyte subsets and not in whole blood. If a clinically applicable test could be devised based on these findings it could have some utility in predicting relapse in GPA. Calprotectin (S100A8/S100A9) is a damage associated molecular pattern produced by neutrophils and monocytes, and is commonly raised in inflammatory conditions. In a subset of 27 patients with early systemic AAV recruited into the NORAM study, levels of calprotectin over $626 \mathrm{ng} / \mathrm{mL}$ at one month after treatment was initiated were associated with future relapse, with a sensitivity of $72.6 \%$ and a specificity of $92.3 \%$, and similarly higher calprotectin levels at 6 months were also significantly associated with relapse. ${ }^{82}$ Serum calprotectin levels are now being prospectively assessed as biomarkers for relapse in AAV. Urinary monocyte chemoattractant protein 1 levels were associated with active renal vasculitis; however, it has not yet been determined whether these changes occur earlier than other clinical evidence of renal vasculitis, and therefore whether they have value in predicting relapse. ${ }^{83}$

\section{Improving the efficacy of maintenance therapy for GPA}

Once patients with GPA attain clinical remission, they are switched to a less toxic maintenance regimen. However, relapse commonly occurs, and some patients will have several relapses during their lifetime, leading to accumulation of disease-associated damage and drug-related toxicity. A number of clinical trials have compared the safety and efficacy of remission maintenance agents in AAV (Table 5), and trials that are ongoing are listed in Table 6.

\section{Trials comparing maintenance therapies in GPA}

The IMPROVE (International Mycophenolate Mofetil Protocol to Reduce Outbreaks of Vasculitides) study found that MMF was less effective at maintaining remission than azathioprine in $\mathrm{AAV}^{84}$ Therefore, MMF is usually reserved for patients who do not tolerate azathioprine. The WEGENT (Wegener's Granulomatosis-Entretien/Maintenance) study found no differences in efficacy or safety between 
Table 5 Completed multicenter randomized controlled trials of remission maintenance therapy in AAV

\begin{tabular}{|c|c|c|c|c|c|c|}
\hline $\begin{array}{l}\text { Maintenance } \\
\text { trials }\end{array}$ & Indication & Induction & $\begin{array}{l}\text { Maintenance } \\
\text { (trial) }\end{array}$ & $\begin{array}{l}\text { Maintenance } \\
\text { (control) }\end{array}$ & $\begin{array}{l}\text { Primary } \\
\text { endpoint }\end{array}$ & Brief results \\
\hline CYCAZAREM $^{56}$ & $\begin{array}{l}\text { Newly diagnosed GPA } \\
\text { or MPA, with renal or } \\
\text { multiorgan involvement }\end{array}$ & $\begin{array}{l}\text { Oral Cyc + } \\
\text { Pred }\end{array}$ & $\begin{array}{l}\text { Aza }+ \text { Pred } \\
(n=7 I)\end{array}$ & $\begin{array}{l}\text { Oral Cyc + Pred } \\
(n=73)\end{array}$ & Relapse rate & $\begin{array}{l}\text { No difference in relapse } \\
\text { rate at } 18 \text { months }\end{array}$ \\
\hline IMPROVE ${ }^{84}$ & $\begin{array}{l}\text { Newly diagnosed GPA } \\
\text { or MPA }\end{array}$ & Cyc + Pred & $\begin{array}{l}\text { MMF + Pred } \\
(n=76)\end{array}$ & $\begin{array}{l}\text { Aza + Pred } \\
(n=80)\end{array}$ & $\begin{array}{l}\text { Relapse-free } \\
\text { survival }\end{array}$ & $\begin{array}{l}\text { MMF less effective } \\
\text { than Aza in maintaining } \\
\text { remission. No difference } \\
\text { in adverse events }\end{array}$ \\
\hline WEGENT ${ }^{85}$ & $\begin{array}{l}\text { GPA or MPA with } \\
\text { renal or multiorgan } \\
\text { involvement }\end{array}$ & $\begin{array}{l}\text { IV Cyc + } \\
\text { Pred }\end{array}$ & $\begin{array}{l}\text { Mtx }+ \text { Pred } \\
(n=63)\end{array}$ & $\begin{array}{l}\text { Aza }+ \text { Pred } \\
(n=63)\end{array}$ & $\begin{array}{l}\text { Adverse event } \\
\text { causing treatment } \\
\text { cessation or death }\end{array}$ & $\begin{array}{l}\text { No difference in adverse } \\
\text { events or relapse }\end{array}$ \\
\hline WGET ${ }^{86}$ & GPA and BVAS $>3$ & $\begin{array}{l}\text { IV Cyc/oral Mt } \\
+ \text { Pred } \pm \text { Etn }\end{array}$ & $\begin{array}{l}\text { Aza or Mtx } \\
\text { plus Etn } \\
(\mathrm{n}=89)\end{array}$ & $\begin{array}{l}\text { Aza or Mtx } \\
(n=92)\end{array}$ & $\begin{array}{l}\text { Remission for } \\
>6 \text { months }\end{array}$ & $\begin{array}{l}\text { Etn failed to improve } \\
\text { sustained remission rates. } \\
\text { No difference in adverse } \\
\text { events. }\end{array}$ \\
\hline $\begin{array}{l}\text { German Network } \\
\text { of Rheumatic } \\
\text { Diseases study }{ }^{87}\end{array}$ & $\begin{array}{l}\text { GPA and creatinine } \\
<1.3 \mathrm{mg} / \mathrm{dL}\end{array}$ & $\begin{array}{l}\text { Oral Cyc + } \\
\text { Pred }\end{array}$ & $\begin{array}{l}\text { Lef }+ \text { pred } \\
(n=26)\end{array}$ & $\begin{array}{l}\text { Mtx }+ \text { pred } \\
(n=28)\end{array}$ & Relapse & $\begin{array}{l}\text { Lef at } 30 \mathrm{mg} / \text { day more } \\
\text { effective than Mtx in } \\
\text { maintaining remission but } \\
\text { with more adverse events }\end{array}$ \\
\hline
\end{tabular}

Abbreviations: AAV, anti-neutrophil cytoplasm antibody-associated small vessel vasculitides; BVAS, Birmingham Vasculitis Activity Index; GPA, granulomatosis with polyangiitis; MPA, microscopic polyangiitis; Aza, azathioprine; Cyc, cyclophosphamide; Mtx, methotrexate; MMF, mycophenolate mofetil; Pred, prednisolone or prednisone; Lef, leflunomide; Etn, etanercept; IV, intravenous; CYCAZAREM, Cyclophosphamide vs azathioprine for early remission phase of vasculitis; IMPROVE, International Mycophenolate Mofetil Protocol to Reduce Outbreaks of Vasculitides; WEGENT, Wegener's Granulomatosis-Entretien/Maintenance; WGET, Wegener's Granulomatosis Etanercept Trial.

azathioprine and methotrexate for maintenance of remission, and so they are considered equivalent, ${ }^{85}$ although methotrexate cannot be used in patients with significant renal dysfunction. Etanercept was not effective as an add-on maintenance strategy in $\mathrm{AAV}^{86}$ Leflunomide is an alternative maintenance agent, usually reserved for patients intolerant of other agents, given that the clinical trial suggested more adverse events than methotrexate. ${ }^{87}$
Eighteen-month follow-up data from the RAVE study demonstrated that patients treated with rituximab and corticosteroids alone had the same relapse rate as patients treated with cyclophosphamide followed by azathioprine maintenance. ${ }^{64}$ Patients who achieved remission in this study were weaned off oral glucocorticoids. One third of patients relapsed during the study, and therefore neither regimen was very effective at maintaining remission in this

Table 6 Trials of maintenance therapy in AAV in progress or completed and not yet published

\begin{tabular}{|c|c|c|c|c|c|c|}
\hline Trial & Indication & Induction & $\begin{array}{l}\text { Maintenance } \\
\text { (trial) }\end{array}$ & $\begin{array}{l}\text { Maintenance } \\
\text { (control) }\end{array}$ & Primary endpoint & $\begin{array}{l}\text { Trial } \\
\text { number }\end{array}$ \\
\hline \multicolumn{7}{|c|}{ Maintenance trials } \\
\hline REMAIN $^{|3|}$ & $\begin{array}{l}\text { GPA or MPA patients who } \\
\text { remain c-ANCA positive } \\
\text { in remission }(n=180)\end{array}$ & Cyc + Pred & Aza for 48 months & Aza for 18 months & $\begin{array}{l}\text { Disease-free survival } \\
\text { during } 48 \text { months of } \\
\text { follow-up }\end{array}$ & NCT00I 28895 \\
\hline MAINRITSAN ${ }^{90}$ & $\begin{array}{l}\text { New or relapsed GPA or } \\
\text { MPA within a month of } \\
\text { remission ( } n=117)\end{array}$ & Cyc + Pred & $\begin{array}{l}\text { Rtx } 0.5 \mathrm{mg} \text { every } \\
6 \text { months with last } \\
\text { dose at month } 18\end{array}$ & $\begin{array}{l}\text { Aza } 2 \mathrm{mg} / \mathrm{kg} \text { tapering } \\
\text { from } 12 \text { months to } \\
\text { zero at } 22 \text { months }\end{array}$ & $\begin{array}{l}\text { Number of major } \\
\text { relapses }(B V A S>10) \\
\text { within } 28 \text { months }\end{array}$ & NCT00748644 \\
\hline RITAZAREM ${ }^{91}$ & $\begin{array}{l}\text { Relapsing GPA or MPA } \\
(n=190)\end{array}$ & Rtx + Pred & $\begin{array}{l}\text { Rtx I g every } \\
4 \text { months for } 2 \text { years } \\
\text { then monitor for } \\
2 \text { years }\end{array}$ & $\begin{array}{l}\text { Aza for } 2 \text { years, then } \\
\text { monitor for } 2 \text { years }\end{array}$ & Time to first relapse & NCT0I697267 \\
\hline BREVAS $^{132}$ & $\begin{array}{l}\text { ANCA-positive GPA or } \\
\text { MPA in remission treated } \\
\text { for active disease in past } \\
26 \text { weeks }(n=400)\end{array}$ & $\begin{array}{l}\text { Cyc }+ \text { Pred } \\
\text { or Rtx }+ \\
\text { Pred }\end{array}$ & $\begin{array}{l}\text { Belimumab plus Aza } \\
2 \mathrm{mg} / \mathrm{kg}\end{array}$ & $\begin{array}{l}\text { Placebo plus Aza } \\
2 \mathrm{mg} / \mathrm{kg}\end{array}$ & Time to first relapse & NCT0I663623 \\
\hline
\end{tabular}

Abbreviations: AAV, anti-neutrophil cytoplasm antibody-associated small vessel vasculitides; Cyc, cyclophosphamide; Pred, prednisone or prednisolone; Rtx, rituximab; Aza, azathioprine; BVAS, Birmingham Vasculitis Activity Index; REMAIN, Randomized trial of prolonged remission-maintenance therapy in systemic vasculitis; MAINRITSAN, Efficacy Study of Two Treatments in the Remission of Vasculitis; RITAZAREM, Rituximab Vasculitis Maintenance Study; BREVAS, Belimumab in Remission of VASculitis; GPA, granulomatosis with polyangiitis; MPA, microscopic polyangiitis; ANCA, anti-neutrophil cytoplasm antibody. 
setting. Two cohort studies have demonstrated that in relapsing patients, scheduled maintenance therapy with rituximab appears to be an effective option for maintaining remission in AAV, although relapses did occur after discontinuation. ${ }^{88,89}$ The relative efficacy of azathioprine maintenance compared with scheduled rituximab retreatment has been investigated in MAINRITSAN (Efficacy Study of Two Treatments in the Remission of Vasculitis), a randomized study that has been published in abstract form and showing superior disease control in patients maintained on rituximab..$^{90}$ In addition, RITAZAREM (the Rituximab Vasculitis Maintenance Study), ${ }^{91}$ comparing rituximab or azathioprine maintenance is currently ongoing. The cumulative effects of rituximab therapy in AAV are unknown. There have been a few reports of John Cunningham (JC) virus infection leading to progressive multifocal leukoencephalopathy following rituximab, although these cases have involved patients exposed to significant immunosuppression over a period of time..$^{92}$ The other long-term complication ascribed to rituximab is hypogammaglobulinemia, which again seems to be related to cumulative exposure to immunosuppression. ${ }^{93}$ There is an obligation therefore to try to avoid excessive immunosuppression, even in patients at risk of relapse, and means to better predict relapse are urgently required.

\section{Evidence to determine duration of maintenance therapy in GPA}

The optimal duration of corticosteroid and maintenance immunosuppressant treatment in GPA is not known, and in reality is likely to vary between individual patients. In one retrospective study, withdrawal of corticosteroid treatment at 6 months was associated with reduced infections and no increase in relapse rate compared with those maintained on corticosteroids. ${ }^{94}$ However, in other studies, early withdrawal of steroids has been associated with increased relapse rates. ${ }^{80}$ A randomized trial to compare maintenance of patients presenting with PR3-ANCA-positive disease using azathioprine for 2 years or 4 years has been reported in abstract form. ${ }^{95}$ It was reported that there was no significant improvement in relapse-free survival with the extended course of azathioprine at 48 months, with relapse rates of $52 \%-74 \%$ in the different groups. It is likely that remission maintenance strategies will evolve significantly once the results of current trials are available.

\section{Management of localized GPA}

For localized disease, a multidisciplinary approach with close communication between otolaryngologists, ophthalmologists, and physicians is required. Systemic immunosuppression combined with local therapy is often necessary. There is evidence of the efficacy of cotrimoxazole in preventing relapse of upper respiratory tract GPA, possibly due to the elimination of nasal carriage of Staphylococcus aureus. ${ }^{96,97}$ Localized disease can sometimes be treated with methotrexate, but it is our practice to reserve this treatment for manifestations where the risk of long-term damage is low, based on the results of the NORAM study. ${ }^{60}$ There have been reports that rituximab is less effective in treating granulomatous upper airways manifestations of GPA than generalized disease, ${ }^{98}$ but this finding has not been confirmed in all studies..$^{99,100}$ The time course of response for granulomatous disease differs from vasculitic manifestations, with a more delayed response, and this may have affected the assessment of response to rituximab in studies with less than 6 months of follow-up. Obstructive tracheobronchial disease can be poorly responsive to systemic therapy, and if not effectively treated, can lead to permanent tracheal scarring with respiratory compromise and increased susceptibility to chest infections. In addition to systemic treatment, active tracheobronchial disease can be treated locally with intralesional steroids and endoluminal surgery with intralesional laser and dilatation. ${ }^{101-103}$ Tracheal endoscopy can be used to monitor treatment response. Nasal and sinus disease can be managed locally with intranasal corticosteroids, and regular saline douching of nasal crusts. Middle ear obstruction may require insertion of grommets. Reconstructive surgery for nasal bridge collapse is an option, but is only recommended in the absence of active nasal vasculitis.

\section{Management of damage and disease/ treatment-associated comorbidity}

Compared with age-matched and sex-matched controls in the general population, a study of 535 patients with AAV enrolled into four EUVAS trials showed a mortality rate of 2.6. ${ }^{8}$ Fortyfour percent of the deaths during the 5-year follow-up of this study occurred within the first year after induction therapy, and the main causes of death in the first year were infection $(48 \%)$ and active vasculitis (19\%). ${ }^{8}$ It is not currently clear which component of induction therapy contributes most to the risk of infection. Half of the infections occurring in the first year were observed during the first 2 months of induction treatment, and unspecified septicemia and bacterial infections of the respiratory tract accounted for half of the cases. ${ }^{52}$ Cumulative adverse events during induction therapy are significantly associated with mortality. ${ }^{52}$ Elderly patients and those with severe renal impairment are particularly 
susceptible to treatment-associated complications..$^{55,104}$ Cotrimoxazole is routinely given to patients receiving cyclophosphamide as prophylaxis against Pneumocystis jirovecii pneumonia. $^{105}$

After the first year, the major causes of death in the EUVAS cohorts were cardiovascular disease (26\%), malignancy $(22 \%)$, and infection $(20 \%){ }^{8}$ Long-term follow-up data from these trials after 7.3 years of follow-up showed a significant burden of morbidity, with $34.4 \%$ of patients having more than five items of damage on the Vasculitis Damage Index at long-term follow-up. ${ }^{48}$ In patients with GPA, the commonest items of damage were nasal blockage/crusting (44.3\%), hypertension (39.5\%), hearing loss $(32.3 \%)$, and a glomerular filtration rate $<50 \mathrm{~mL}$ per minute (31.7\%). Impaired pulmonary function (13.8\%) and peripheral neuropathy $(22.2 \%)$ were also prominent features. Cardiovascular endpoints of angina/coronary artery bypass, stroke, and myocardial infarction were also significantly increased. ${ }^{48,106}$ In view of this, attention must be drawn to management of cardiovascular risk factors, including smoking, exercise, hypertension, weight management, lipids, and management of diabetes, where present. End-stage renal disease occurs in up to $25 \%$ of patients with $\mathrm{AAV}^{8}$ Dialysis and renal transplantation are options for these patients, and patients with AAV have good outcomes of transplantation when it is performed after disease activity is controlled. ${ }^{107}$ More difficult to manage is permanent lung scarring due to pulmonary fibrosis and respiratory compromise due to tracheal and bronchial stenosis, which can also predispose to recurrent chest infections.

Damage in GPA is not only related to the disease itself, but also to treatment. Short-term and long-term toxicities associated with treatments commonly used for GPA are listed in Table 2. In the EUVAS trials, potential treatmentrelated damage items were reported for two thirds of patients. Cohorts of GPA patients exposed to high cumulative doses of cyclophosphamide have been shown to be at an increased risk of bladder malignancy (standardized incidence ratio [SIR] 3.6-4.8), ${ }^{49-51}$ acute myeloid leukemia, ${ }^{50}$ (SIR 19.6), and nonmelanoma skin cancer (SIR 4.7). ${ }^{50}$ The risk is known to be dose-dependent, and increase substantially with cumulative doses of cyclophosphamide over $25 \mathrm{~g},{ }^{49,50}$ but a safe threshold dose for cyclophosphamide has not been established. However, the risks of bladder malignancy, leukemia, and nonmelanoma skin cancer in the recent EUVAS trials were lower than in previous cohorts (SIR 2.4, 3.2, and 2.8, respectively), probably due to reduced cyclophosphamide exposure. ${ }^{47}$ Azathioprine has been associated with nonmelanoma skin cancer in other conditions; ${ }^{108,109}$ however, in AAV, it is rarely used alone and so its contribution to skin cancer in GPA is difficult to quantify. Recommendations for treatment of AAV, including prophylaxis for the prevention of treatment-associated complications have been produced. ${ }^{105,110}$

\section{Management of GPA in the future}

There is an ongoing need to reduce the toxicity of treatment for GPA, and to increase the efficacy of maintenance therapy in preventing relapse. Currently, a means to restore immunological tolerance to ANCA autoantigens in AAV does not exist. However, the development of biological therapeutics and small molecules targeting specific cell types, cytokines, and immunological pathways has enabled more rational drug targeting in inflammatory diseases. A number of new therapeutics targeting immunological pathways have a rationale for efficacy in $\mathrm{AAV}$, and these are discussed below and shown in Figure 1. Most have yet to be formally evaluated for this indication. Clinical trials of emerging therapeutics for AAV that are currently ongoing are listed in Tables 4 and 6.

\section{B cells}

Rituximab, a chimeric human/mouse anti-CD20 B cell-depleting agent, has proven efficacy as induction therapy in $\mathrm{AAV}$ and is being evaluated for maintenance of remission. ${ }^{62,63,91}$ Fully humanized CD20 monoclonal antibodies have been developed, including ofatumumab, ocrelizumab, and veltuzumab. Ofatumumab has been licensed for treatment of resistant chronic lymphocytic leukemia. ${ }^{11}$ These agents are not currently licensed for treatment of AAV, but they have been used "off label" in patients who have allergic reactions to rituximab.

$\mathrm{B}$ cell activating factor (BlyS) is a cytokine involved in the proliferation and maturation of B cells. ANCA-stimulated neutrophils release BlyS, and BlyS levels have been shown to be elevated in patients with GPA. ${ }^{112-114}$ Belimumab is a fully humanized monoclonal antibody to soluble BlyS, which is currently being evaluated in Phase II studies as a relapse prevention agent in AAV (Table 6).

Epratuzumab is an anti-CD22 monoclonal antibody expressed on follicular B cells in germinal centers. CD22 is a transmembrane sialoglycoprotein involved in negative regulation of signaling via the $\mathrm{B}$ cell receptor, and is also involved in B cell migration. ${ }^{15}$ This agent has not yet been evaluated for AAV indications, but is being investigated in a Phase III study for nonrenal systemic lupus erythematosus. ${ }^{116}$ 


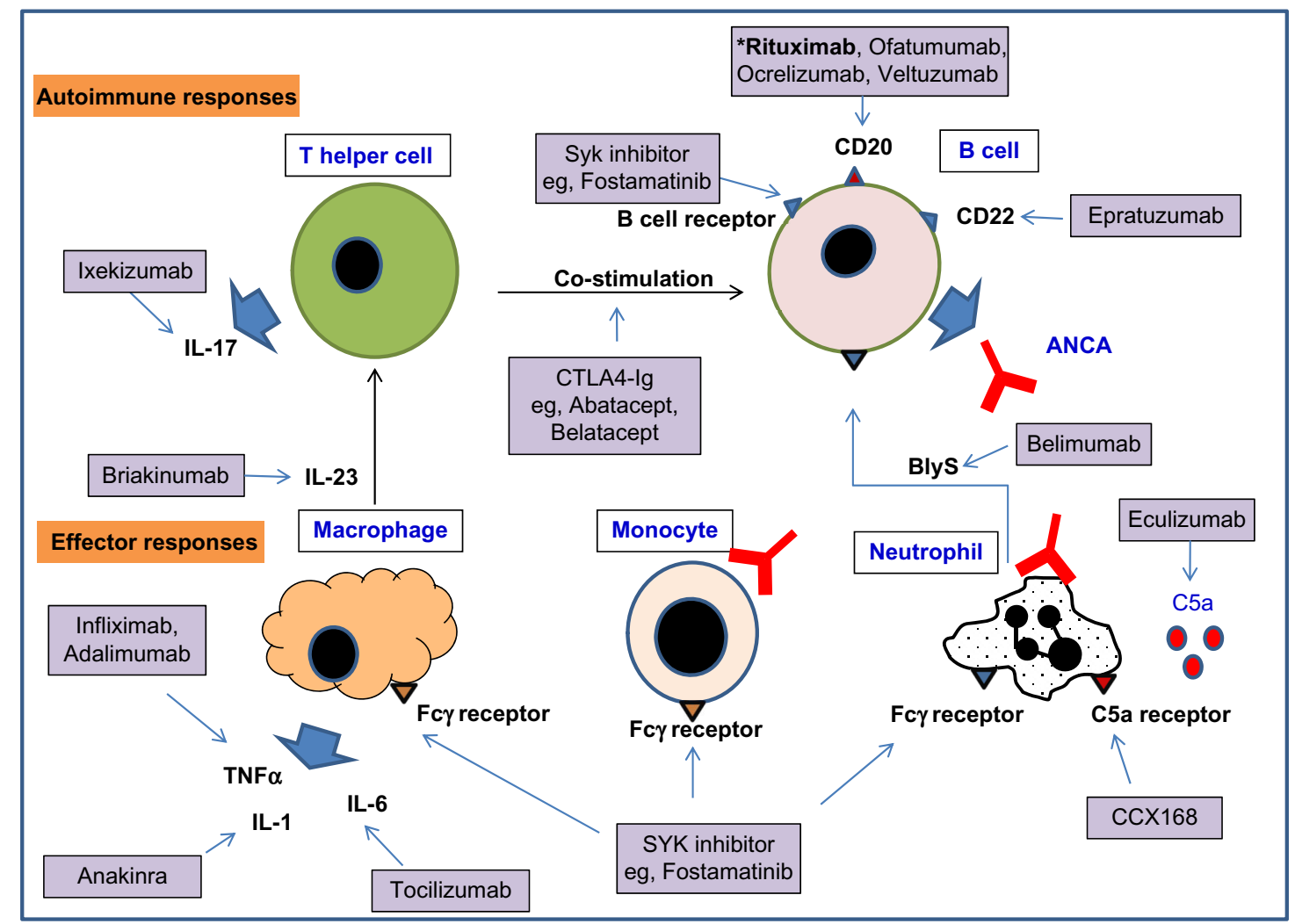

Figure I A selection of biologics and small molecule inhibitors targeting the autoimmune response and effector responses that may be important in GPA. Note: *Of these agents, only rituximab is currently licensed for the treatment of GPA, but some of the others are currently undergoing clinical trial evaluation. Abbreviations: ANCA, anti-neutrophil cytoplasm antibody; GPA, granulomatosis with polyangiitis; IL, interleukin; CCXI68, C5a receptor antagonist; BlyS, B cell activating factor; TNF, tumor necrosis factor; CD, cluster of differentiation; ANCA, Anti-neutrophil cytoplasm antibody; SYK, spleen tyrosine kinase.

\section{T cells}

$\mathrm{T}$ effector memory cells are present in chronic vasculitic lesions in patients with GPA, ${ }^{24,25}$ and $\mathrm{T}$ cell help is also required for generation of ANCA. Targeting $\mathrm{T}$ cell costimulation with CTLA4-Ig, abatacept, showed promising results in a small open-label study. ${ }^{117}$ Lymphocyte depletion with anti-CD52 (Campath-1 $\left.\mathrm{H}^{\circledR}\right)$ caused reductions in circulating lymphocytes, including CD4 T cells and was used in a small study in refractory AAV (total dose $134 \mathrm{mg}) .{ }^{76}$ Whilst effective in these difficult-to-treat patients, the infection rate was high, and so now a second study is ongoing using lower doses of Campath-1H (30 $\mathrm{mg}$ or $60 \mathrm{mg}$ ) in 24 patients with refractory AAV. ${ }^{118}$ Raised serum levels of IL-23 and IL-17 and antigen-specific Th17 cells have been demonstrated in AAV, ${ }^{26}$ implicating the Th17 pathway in pathogenesis. Agents targeting the Th17 axis (inhibitors of IL-17, IL-17 receptor, and IL-12/ IL-23) are under development, in particular for resistant psoriasis, ${ }^{119-121}$ but these agents have not been evaluated for safety or efficacy in AAV.

\section{Complement}

Raised levels of alternative pathway complement breakdown products have been detected in the serum of patients with active AAV and in kidney biopsy specimens. ${ }^{31,32}$ There is also evidence of the importance of the alternative pathway of complement in a mouse model of MPO-positive vasculitis. ${ }^{33} \mathrm{C} 5 \mathrm{a}$ is a potent neutrophil chemoattractant, and C5a receptor signaling increases the expression of activatory $\mathrm{Fc}$ gamma receptors on neutrophils. ${ }^{122}$ These data make $\mathrm{C} 5 \mathrm{a}$ and its receptor a potential anti-inflammatory target in AAV. The CLEAR study is evaluating an orally bioavailable $\mathrm{C} 5$ a receptor antagonist as a steroid-sparing agent in induction therapy in $\mathrm{AAV}^{67}$

\section{Cytokines and small molecule signaling inhibitors}

TNF- $\alpha$ primes neutrophil responses to ANCA, and increases the expression of PR3 on the neutrophil surface. ${ }^{15}$ In small studies, blockade of TNF- $\alpha$ by monoclonal antibodies has appeared to be effective in having a steroid-sparing effect in $\mathrm{AAV}^{78,123}$ However, the TNF receptor blocker etanercept 
failed to show benefit in a larger study. ${ }^{86}$ Anti-TNF antibodies block both soluble and membrane-bound TNF- $\alpha$, whilst etanercept blocks only the effects of soluble TNF- $\alpha$, and this might account for the differing results. However, due to the results with etanercept, TNF- $\alpha$ blockade has not subsequently been evaluated in AAV in a large clinical trial. Blockade of the IL- 6 and IL-1 $\beta$ pathways are other potential anti-inflammatory targets that have not yet been evaluated in AAV.

Spleen tyrosine kinase (SYK) is a nonreceptor tyrosine kinase that transmits intracellular signals for the B cell receptor and activatory Fc gamma receptors, amongst other immunoreceptors. SYK inhibitors not only target antibody production, but also downstream effector mechanisms. Fostamatinib, an orally bioavailable inhibitor of SYK, has been found to be highly effective in rat experimental autoimmune glomerulonephritis and nephrotoxic nephritis. ${ }^{124,125}$ Fostamatinib has been shown to have efficacy in rheumatoid arthritis in a Phase II study, ${ }^{126}$ but has not been evaluated in AAV.

\section{Conclusion}

Management of GPA requires a multidisciplinary approach, aiming not only to treat the disease and prevent relapse, but also to manage long-term cardiovascular risk, organ damage, and side effects of therapy. Treatments have been refined as a result of large multicenter randomized controlled trials in AAV; however, there are unmet needs to resolve granulomatous inflammation more rapidly, to reduce steroid exposure, and to improve the efficacy of remission maintenance strategies in GPA. There are a large number of potentially promising agents for the treatment of AAV in development, and clinical trials will be required to determine whether these can meet unmet needs for patients with GPA.

\section{Disclosure}

CDP has received research funding from GlaxoSmithKline.

The authors report no other conflicts of interest in this work.

\section{References}

1. Seo P, Stone JH. The antineutrophil cytoplasmic antibody-associated vasculitides. Am J Med. 2004;117:39-50.

2. Jennette JC, Falk RJ, Bacon PA, et al. 2012 Revised International Chapel Hill Consensus Conference nomenclature of vasculitides. Arthritis Rheum. 2013;65:1-11.

3. Hoffman GS, Kerr GS, Leavitt RY, et al. Wegener granulomatosis: an analysis of 158 patients. Ann Intern Med. 1992;116:488-498.

4. Falk RJ, Hogan S, Carey TS, Jennette JC. Clinical course of anti-neutrophil cytoplasmic autoantibody-associated glomerulonephritis and systemic vasculitis. The Glomerular Disease Collaborative Network. Ann Intern Med. 1990;113:656-663.
5. Niles JL, Bottinger EP, Saurina GR, et al. The syndrome of lung hemorrhage and nephritis is usually an ANCA-associated condition. Arch Intern Med. 1996;156:440-445.

6. Watts RA, Lane SE, Bentham G, Scott DG. Epidemiology of systemic vasculitis: a ten-year study in the United Kingdom. Arthritis Rheum. 2000;43:414-419.

7. Booth AD, Almond MK, Burns A, et al. Outcome of ANCA-associated renal vasculitis: a 5-year retrospective study. Am J Kidney Dis. 2003; 41:776-784.

8. Flossmann O, Berden A, de Groot K, et al. Long-term patient survival in ANCA-associated vasculitis. Ann Rheum Dis. 2011;70: 488-494.

9. Miloslavsky E, Specks U, Merkel P, et al. Clinical outcomes of remission induction therapy for severe ANCA-associated vasculitis. Arthritis Rheum. 2013;65:2441-2449.

10. Pagnoux C, Hogan SL, Chin H, et al. Predictors of treatment resistance and relapse in antineutrophil cytoplasmic antibody-associated smallvessel vasculitis: comparison of two independent cohorts. Arthritis Rheum. 2008;58:2908-2918.

11. Jennette JC, Falk RJ, Hu P, Xiao H. Pathogenesis of antineutrophil cytoplasmic autoantibody-associated small-vessel vasculitis. Annu Rev Pathol. 2013;8:139-160.

12. Tarzi RM, Cook HT, Pusey CD. Crescentic glomerulonephritis: new aspects of pathogenesis. Semin Nephrol. 2011;31:361-368.

13. Ludemann J, Utecht B, Gross WL. Anti-cytoplasmic antibodies in Wegener's granulomatosis are directed against proteinase 3. Adv Exp Med Biol. 1991;297:141-150.

14. Falk RJ, Jennette JC. Anti-neutrophil cytoplasmic autoantibodies with specificity for myeloperoxidase in patients with systemic vasculitis and idiopathic necrotizing and crescentic glomerulonephritis. $N$ Engl JMed. 1988;318:1651-1657.

15. Csernok E, Ernst M, Schmitt W, Bainton DF, Gross WL. Activated neutrophils express proteinase 3 on their plasma membrane in vitro and in vivo. Clin Exp Immunol. 1994;95:244-250.

16. Harper L, Cockwell P, Adu D, Savage CO. Neutrophil priming and apoptosis in anti-neutrophil cytoplasmic autoantibody-associated vasculitis. Kidney Int. 2001;59:1729-1738.

17. Hattar K, van Burck S, Bickenbach A, et al. Anti-proteinase 3 antibodies (c-ANCA) prime CD14-dependent leukocyte activation.J Leukoc Biol. 2005;78:992-1000.

18. Savage CO, Pottinger BE, Gaskin G, Pusey CD, Pearson JD. Autoantibodies developing to myeloperoxidase and proteinase 3 in systemic vasculitis stimulate neutrophil cytotoxicity toward cultured endothelial cells. Am J Pathol. 1992;141:335-342.

19. Radford DJ, Savage CO, Nash GB. Treatment of rolling neutrophils with antineutrophil cytoplasmic antibodies causes conversion to firm integrin-mediated adhesion. Arthritis Rheum. 2000;43:1337-1345.

20. Bansal PJ, Tobin MC. Neonatal microscopic polyangiitis secondary to transfer of maternal myeloperoxidase-antineutrophil cytoplasmic antibody resulting in neonatal pulmonary hemorrhage and renal involvement. Ann Allergy Asthma Immunol. 2004;93:398-401.

21. Little MA, Smyth CL, Yadav R, et al. Antineutrophil cytoplasm antibodies directed against myeloperoxidase augment leukocyte-microvascular interactions in vivo. Blood. 2005;106:2050-2058.

22. Xiao H, Heeringa P, Hu P, et al. Antineutrophil cytoplasmic autoantibodies specific for myeloperoxidase cause glomerulonephritis and vasculitis in mice. J Clin Invest. 2002;110:955-963.

23. Little MA, Al-Ani B, Ren S, et al. Anti-proteinase 3 anti-neutrophil cytoplasm autoantibodies recapitulate systemic vasculitis in mice with a humanized immune system. PLoS One. 2012;7:e28626.

24. Abdulahad WH, Kallenberg CG, Limburg PC, Stegeman CA. Urinary $\mathrm{CD} 4+$ effector memory $\mathrm{T}$ cells reflect renal disease activity in antineutrophil cytoplasmic antibody-associated vasculitis. Arthritis Rheum. 2009;60:2830-2838.

25. Abdulahad WH, Stegeman CA, Limburg PC, Kallenberg CG. CD4positive effector memory $\mathrm{T}$ cells participate in disease expression in ANCA-associated vasculitis. Ann N Y Acad Sci. 2007;1107:22-31. 
26. Nogueira E, Hamour S, Sawant D, et al. Serum IL-17 and IL-23 levels and autoantigen-specific Th17 cells are elevated in patients with ANCA-associated vasculitis. Nephrol Dial Transplant. 2010;25: 2209-2217.

27. Free ME, Bunch DO, McGregor J, et al. ANCA-associated vasculitis patients have defective Treg function exacerbated by presence of a suppression-resistant effector population. Arthritis Rheum. 2013;65:1922-1933.

28. Morgan MD, Day CJ, Piper KP, et al. Patients with Wegener's granulomatosis demonstrate a relative deficiency and functional impairment of T-regulatory cells. Immunology. 2010;130:64-73.

29. Wilde B, Thewissen M, Damoiseaux J, et al. Regulatory B cells in ANCA-associated vasculitis. Ann Rheum Dis. 2013;72:1416-1419.

30. Bunch DO, McGregor JG, Khandoobhai NB, et al. Decreased CD5(+) B cells in active ANCA vasculitis and relapse after rituximab. Clin J Am Soc Nephrol. 2013;8:382-391.

31. Gou SJ, Yuan J, Chen M, Yu F, Zhao MH. Circulating complement activation in patients with anti-neutrophil cytoplasmic antibody-associated vasculitis. Kidney Int. 2013;83:129-137.

32. Gou SJ, Yuan J, Wang C, Zhao MH, Chen M. Alternative complement pathway activation products in urine and kidneys of patients with ANCA-associated GN. Clin J Am Soc Nephrol. 2013;8: 1884-1891.

33. Xiao H, Dairaghi DJ, Powers JP, et al. C5a receptor (CD88) blockade protects against MPO-ANCA GN. J Am Soc Nephrol. 2014;25: 225-231.

34. Lyons PA, Rayner TF, Trivedi S, et al. Genetically distinct subsets within ANCA-associated vasculitis. $N$ Engl J Med. 2012;367:214-223.

35. Falk RJ, Jennette JC. ANCA disease: where is this field heading? J Am Soc Nephrol. 2010;21:745-752.

36. Martinez Del Pero M, Walsh M, Luqmani R, et al. Long-term damage to the ENT system in Wegener's granulomatosis. Eur Arch Otorhinolaryngol. 2011;268:733-739.

37. Haworth SJ, Savage CO, Carr D, Hughes JM, Rees AJ. Pulmonary haemorrhage complicating Wegener's granulomatosis and microscopic polyarteritis. Br Med J (Clin Res Ed). 1985;290:1775-1778.

38. Holle JU, Gross WL, Holl-Ulrich K, et al. Prospective long-term follow-up of patients with localised Wegener's granulomatosis: does it occur as persistent disease stage? Ann Rheum Dis. 2010;69: 1934-1199.

39. Stone JH; Wegener's Granulomatosis Etanercept Trial Research Group. Limited versus severe Wegener's granulomatosis: baseline data on patients in the Wegener's granulomatosis etanercept trial. Arthritis Rheum. 2003;48:2299-2309.

40. Hogan SL, Falk RJ, Chin H, et al. Predictors of relapse and treatment resistance in antineutrophil cytoplasmic antibody-associated smallvessel vasculitis. Ann Intern Med. 2005;143:621-631.

41. Arulkumaran N, Periselneris N, Gaskin G, et al. Interstitial lung disease and ANCA-associated vasculitis: a retrospective observational cohort study. Rheumatology (Oxford). 2011;50:2035-2043.

42. Mukhtyar C, Flossmann O, Hellmich B, et al. Outcomes from studies of antineutrophil cytoplasm antibody associated vasculitis: a systematic review by the European League Against Rheumatism systemic vasculitis task force. Ann Rheum Dis. 2008;67:1004-1010.

43. Walsh M, Flossmann O, Berden A, et al. Risk factors for relapse of antineutrophil cytoplasmic antibody-associated vasculitis. Arthritis Rheum. 2012;64:542-548.

44. Tomasson G, Grayson PC, Mahr AD, Lavalley M, Merkel PA. Value of ANCA measurements during remission to predict a relapse of ANCA-associated vasculitis - a meta-analysis. Rheumatology (Oxford). 2012;51:100-109.

45. Tervaert JW, van der Woude FJ, Fauci AS, et al. Association between active Wegener's granulomatosis and anticytoplasmic antibodies. Arch Intern Med. 1989;149:2461-2465.

46. Fauci AS, Wolff SM. Wegener's granulomatosis: studies in eighteen patients and a review of the literature. Medicine (Baltimore). 1973;52: 535-661.
47. Heijl C, Harper L, Flossmann O, et al. Incidence of malignancy in patients treated for antineutrophil cytoplasm antibody-associated vasculitis: follow-up data from European Vasculitis Study Group clinical trials. Ann Rheum Dis. 2011;70:1415-1421.

48. Robson J, Doll H, Suppiah R, et al. Damage in the ANCA-associated vasculitides: long-term data from the European Vasculitis Study group (EUVAS) therapeutic trials. Ann Rheum Dis. November 15, 2013. [Epub ahead of print.]

49. Knight A, Askling J, Granath F, Sparen P, Ekbom A. Urinary bladder cancer in Wegener's granulomatosis: risks and relation to cyclophosphamide. Ann Rheum Dis. 2004;63:1307-1311.

50. Faurschou M, Sorensen IJ, Mellemkjaer L, et al. Malignancies in Wegener's granulomatosis: incidence and relation to cyclophosphamide therapy in a cohort of 293 patients. $J$ Rheumatol. 2008;35:100-105.

51. Le Guenno G, Mahr A, Pagnoux C, et al. Incidence and predictors of urotoxic adverse events in cyclophosphamide-treated patients with systemic necrotizing vasculitides. Arthritis Rheum. 2011;63: 1435-1445.

52. Little MA, Nightingale P, Verburgh CA, et al. Early mortality in systemic vasculitis: relative contribution of adverse events and active vasculitis. Ann Rheum Dis. 2010;69:1036-1043.

53. Holle JU, Gross WL, Latza U, et al. Improved outcome in 445 patients with Wegener's granulomatosis in a German vasculitis center over four decades. Arthritis Rheum. 2011;63:257-266.

54. Hilhorst M, Wilde B, van Paassen P, et al. Improved outcome in anti-neutrophil cytoplasmic antibody (ANCA)-associated glomerulonephritis: a 30-year follow-up study. Nephrol Dial Transplant. 2013;28:373-379.

55. Tarzi RM, Pusey CD. Vasculitis: risks and rewards of treating elderly patients with vasculitis. Nat Rev Nephrol. 2011;7:253-255.

56. Jayne D, Rasmussen N, Andrassy K, et al. A randomized trial of maintenance therapy for vasculitis associated with antineutrophil cytoplasmic autoantibodies. N Engl J Med. 2003;349:36-44.

57. de Groot K, Harper L, Jayne DR, et al. Pulse versus daily oral cyclophosphamide for induction of remission in antineutrophil cytoplasmic antibody-associated vasculitis: a randomized trial. Ann Intern Med. 2009;150:670-680.

58. Harper L, Morgan MD, Walsh M, et al. Pulse versus daily oral cyclophosphamide for induction of remission in ANCA-associated vasculitis: long-term follow-up. Ann Rheum Dis. 2012;71:955-960.

59. De Groot K, Rasmussen N, Bacon PA, et al. Randomized trial of cyclophosphamide versus methotrexate for induction of remission in early systemic antineutrophil cytoplasmic antibody-associated vasculitis. Arthritis Rheum. 2005;52:2461-2469.

60. Faurschou M, Westman K, Rasmussen N, et al. Brief report: long-term outcome of a randomized clinical trial comparing methotrexate to cyclophosphamide for remission induction in early systemic antineutrophil cytoplasmic antibody-associated vasculitis. Arthritis Rheum. 2012;64: 3472-3477.

61. Jones RB, Harper L, Ballarin J, et al. [A randomised trial of mycophenolate mofetil versus cyclophosphamide for remission induction of ANCA associated vasculitis]. Presse Med. 2013;42:678. French.

62. Stone JH, Merkel PA, Spiera R, et al. Rituximab versus cyclophosphamide for ANCA-associated vasculitis. $N$ Engl $J$ Med. 2010;363:221-232.

63. Jones RB, Tervaert JW, Hauser T, et al. Rituximab versus cyclophosphamide in ANCA-associated renal vasculitis. $N$ Engl J Med. 2010;363: 211-220.

64. Specks U, Merkel PA, Seo P, et al. Efficacy of remission-induction regimens for ANCA-associated vasculitis. $N$ Engl J Med. 2013;369: 417-427.

65. Voswinkel J, Mueller A, Kraemer JA, et al. B lymphocyte maturation in Wegener's granulomatosis: a comparative analysis of VH genes from endonasal lesions. Ann Rheum Dis. 2006;65:859-864.

66. Walsh M, Merkel PA, Peh CA, et al. Plasma exchange and glucocorticoid dosing in the treatment of anti-neutrophil cytoplasm antibody associated vasculitis (PEXIVAS): protocol for a randomized controlled trial. Trials. 2013;14:73. 
67. ChemoCentryx. A Study to Evaluate the Safety and Efficacy of CCX168 in Subjects With ANCA-Associated Renal Vasculitis. Available from: http://www.clinicaltrials.gov/ct2/show/NCT01363388?term=NCT013 63388\&rank=1. NLM identifier: NCT01363388. Accessed December 11, 2013.

68. Casian A, Jayne, D. Plasma exchange in the treatment of Wegener's granulomatosis, microscopic polyangiitis, Churg-Strauss syndrome and renal limited vasculitis. Curr Opin Rheumatol. 2011;23:12-17.

69. Jayne DR, Gaskin G, Rasmussen N, et al. Randomized trial of plasma exchange or high-dosage methylprednisolone as adjunctive therapy for severe renal vasculitis. J Am Soc Nephrol. 2007;18:2180-2188.

70. Walsh M, Casian A, Flossmann O, et al. Long-term follow-up of patients with severe ANCA-associated vasculitis comparing plasma exchange to intravenous methylprednisolone treatment is unclear. Kidney Int. 2013;84:397-402.

71. Hellmich B, Flossmann O, Gross WL, et al. EULAR recommendations for conducting clinical studies and/or clinical trials in systemic vasculitis: focus on anti-neutrophil cytoplasm antibody-associated vasculitis. Ann Rheum Dis. 2007;66:605-617.

72. Rutgers A, Kallenberg CG. Refractory disease in antineutrophil cytoplasmic antibodies associated vasculitis. Curr Opin Rheumatol. 2012;24:245-251.

73. Roll P, Ostermeier E, Haubitz M, et al. Efficacy and safety of rituximab treatment in patients with antineutrophil cytoplasmic antibodyassociated vasculitides: results from a German registry (GRAID). J Rheumatol. 2012;39:2153-2156.

74. Jayne DR, Chapel H, Adu D, et al. Intravenous immunoglobulin for ANCA-associated systemic vasculitis with persistent disease activity. QJM. 2000;93:433-439.

75. Martinez V, Cohen P, Pagnoux C, et al. Intravenous immunoglobulins for relapses of systemic vasculitides associated with antineutrophil cytoplasmic autoantibodies: results of a multicenter, prospective, open-label study of twenty-two patients. Arthritis Rheum. 2008;58: 308-317.

76. Walsh M, Chaudhry A, Jayne D. Long-term follow-up of relapsing/ refractory anti-neutrophil cytoplasm antibody associated vasculitis treated with the lymphocyte depleting antibody alemtuzumab (CAMPATH-1H). Ann Rheum Dis. 2008;67:1322-1327.

77. Birck R, Warnatz K, Lorenz HM, et al. 15-Deoxyspergualin in patients with refractory ANCA-associated systemic vasculitis: a six-month open-label trial to evaluate safety and efficacy. $J$ Am Soc Nephrol. 2003;14:440-447.

78. Booth A, Harper L, Hammad T, et al. Prospective study of TNFalpha blockade with infliximab in anti-neutrophil cytoplasmic antibody-associated systemic vasculitis. JAm Soc Nephrol. 2004;15: $717-721$.

79. Joy MS, Hogan SL, Jennette JC, Falk RJ, Nachman PH. A pilot study using mycophenolate mofetil in relapsing or resistant ANCA small vessel vasculitis. Nephrol Dial Transplant. 2005;20:2725-2732.

80. Walsh M, Merkel PA, Mahr A, Jayne D. Effects of duration of glucocorticoid therapy on relapse rate in antineutrophil cytoplasmic antibodyassociated vasculitis: a meta-analysis. Arthritis Care Res (Hoboken). 2010;62:1166-1173.

81. McKinney EF, Lyons PA, Carr EJ, et al. A CD8+ T cell transcription signature predicts prognosis in autoimmune disease. Nat Med. 2010;16:586-591.

82. Pepper RJ, Hamour S, Chavele KM, et al. Leukocyte and serum S100A8/S100A9 expression reflects disease activity in ANCAassociated vasculitis and glomerulonephritis. Kidney Int. 2013;83: $1150-1158$

83. Tam FW, Sanders JS, George A, et al. Urinary monocyte chemoattractant protein-1 (MCP-1) is a marker of active renal vasculitis. Nephrol Dial Transplant. 2004;19:2761-2768.

84. Hiemstra TF, Walsh M, Mahr A, et al. Mycophenolate mofetil vs azathioprine for remission maintenance in antineutrophil cytoplasmic antibody-associated vasculitis: a randomized controlled trial. JAMA. 2010;304:2381-2388.
85. Pagnoux C, Mahr A, Hamidou MA, et al. Azathioprine or methotrexate maintenance for ANCA-associated vasculitis. N Engl J Med. 2008;359: 2790-2803.

86. [No authors listed]. The Wegener's granulomatosis etanercept (WGET) research group. Etanercept plus standard therapy for Wegener's granulomatosis. N Engl J Med. 2005;352:351-361.

87. Metzler C, Miehle N, Manger K, et al. Elevated relapse rate under oral methotrexate versus leflunomide for maintenance of remission in Wegener's granulomatosis. Rheumatology (Oxford). 2007;46: 1087-1091.

88. Smith RM, Jones RB, Guerry MJ, et al. Rituximab for remission maintenance in relapsing antineutrophil cytoplasmic antibodyassociated vasculitis. Arthritis Rheum. 2012;64:3760-3769.

89. Cartin-Ceba R, Golbin JM, Keogh KA, et al. Rituximab for remission induction and maintenance in refractory granulomatosis with polyangiitis (Wegener's): ten-year experience at a single center. Arthritis Rheum. 2012;64:3770-3778.

90. Guillevin L, Pagnoux C, Karras A, et al. [Rituximab versus azathioprine for maintenance in ANCA-associated vasculitis. A prospective study in 117 patients. Presse Med]. 2013;42:679.

91. Cambridge University Hospitals NHS Foundation Trust. Rituximab Vasculitis Maintenance Study (RITAZAREM). Available from: http:// www.clinicaltrials.gov/ct2/show/NCT01697267?term=RITAZAREM \&rank=1. NLM identifier: NCT01697267. Accessed July 9, 2013.

92. Molloy ES, Calabrese LH. Progressive multifocal leukoencephalopathy associated with immunosuppressive therapy in rheumatic diseases: evolving role of biologic therapies. Arthritis Rheum. 2012;64: 3043-3051.

93. Besada E, Koldingsnes W, Nossent JC. Long-term efficacy and safety of pre-emptive maintenance therapy with rituximab in granulomatosis with polyangiitis: results from a single centre. Rheumatology (Oxford). 2013;52:2041-2047.

94. McGregor JG, Hogan SL, Hu Y, et al. Glucocorticoids and relapse and infection rates in anti-neutrophil cytoplasmic antibody disease. Clin J Am Soc Nephrol. 2012;7:240-247.

95. De Joode AAE, Sanders JS, Cohen Tervaert JW, Stegeman C. [Randomized clinical trial of extended versus standard azathioprine maintenance therapy in newly diagnosed PR3-ANCA positive vasculitis patients at high risk for disease relapse]. Presse Med. 2013;42:680. French.

96. Zycinska K, Wardyn KA, Zielonka TM, Krupa R, Lukas W. Co-trimoxazole and prevention of relapses of PR3-ANCA positive vasculitis with pulmonary involvement. Eur J Med Res. 2009;14 Suppl 4: 265-267.

97. Stegeman CA, Tervaert JW, de Jong PE, Kallenberg CG. Trimethoprim-sulfamethoxazole (co-trimoxazole) for the prevention of relapses of Wegener's granulomatosis. Dutch Co-Trimoxazole Wegener Study Group. N Engl J Med. 1996;335:16-20.

98. Holle JU, Dubrau C, Herlyn K, et al. Rituximab for refractory granulomatosis with polyangiitis (Wegener's granulomatosis): comparison of efficacy in granulomatous versus vasculitic manifestations. Ann Rheum Dis. 2012;71:327-333.

99. Taylor SR, Salama AD, Joshi L, Pusey CD, Lightman SL. Rituximab is effective in the treatment of refractory ophthalmic Wegener's granulomatosis. Arthritis Rheum. 2009;60:1540-1547.

100. Joshi L, Lightman SL, Salama AD, et al. Rituximab in refractory ophthalmic Wegener's granulomatosis: PR3 titers may predict relapse, but repeat treatment can be effective. Ophthalmology. 2011;118: 2498-2503.

101. Langford CA, Sneller MC, Hallahan CW, et al. Clinical features and therapeutic management of subglottic stenosis in patients with Wegener's granulomatosis. Arthritis Rheum. 1996;39: $1754-1760$

102. Hoffman GS, Thomas-Golbanov CK, Chan J, Akst LM, Eliachar I. Treatment of subglottic stenosis, due to Wegener's granulomatosis, with intralesional corticosteroids and dilation. J Rheumatol. 2003;30: 1017-1021. 
103. Nouraei SA, Obholzer R, Ind PW, et al. Results of endoscopic surgery and intralesional steroid therapy for airway compromise due to tracheobronchial Wegener's granulomatosis. Thorax. 2008;63: 49-52.

104. Harper L, Savage CO. ANCA-associated renal vasculitis at the end of the twentieth century - a disease of older patients. Rheumatology (Oxford). 2005;44:495-501.

105. Mukhtyar C, Guillevin L, Cid MC, et al. EULAR recommendations for the management of primary small and medium vessel vasculitis. Ann Rheum Dis. 2009;68:310-317.

106. Faurschou M, Mellemkjaer L, Sorensen IJ, et al. Increased morbidity from ischemic heart disease in patients with Wegener's granulomatosis. Arthritis Rheum. 2009;60:1187-1192.

107. Moran S, Little MA. Renal transplantation in antineutrophil cytoplasmic antibody-associated vasculitis. Curr Opin Rheumatol. 2014;26:37-41.

108. Asten P, Barrett J, Symmons D. Risk of developing certain malignancies is related to duration of immunosuppressive drug exposure in patients with rheumatic diseases. J Rheumatol. 1999;26: 1705-1714.

109. Setshedi M, Epstein D, Winter TA, et al. Use of thiopurines in the treatment of inflammatory bowel disease is associated with an increased risk of non-melanoma skin cancer in an at-risk population: a cohort study. J Gastroenterol Hepatol. 2012;27:385-389.

110. Lapraik C, Watts R, Bacon P, et al. BSR and BHPR guidelines for the management of adults with ANCA associated vasculitis. Rheumatology (Oxford). 2007;46:1615-1616

111. Barth MJ, Czuczman MS. Ofatumumab: a novel, fully human anti-CD20 monoclonal antibody for the treatment of chronic lymphocytic leukemia. Future Oncol. 2013;9:1829-1839.

112. Holden NJ, Williams JM, Morgan MD, et al. ANCA-stimulated neutrophils release BLyS and promote B cell survival: a clinically relevant cellular process. Ann Rheum Dis. 2011;70:2229-2233.

113. Krumbholz M, Specks U, Wick M, et al. BAFF is elevated in serum of patients with Wegener's granulomatosis. J Autoimmun. 2005;25:298-302.

114. Bader L, Koldingsnes W, Nossent J. B-lymphocyte activating factor levels are increased in patients with Wegener's granulomatosis and inversely correlated with ANCA titer. Clin Rheumatol. 2010;29: 1031-1035.

115. Daridon C, Blassfeld D, Reiter K, et al. Epratuzumab targeting of CD22 affects adhesion molecule expression and migration of B-cells in systemic lupus erythematosus. Arthritis Res Ther. 2010;12:R204.

116. Wallace DJ, Kalunian K, Petri MA, et al. Efficacy and safety of epratuzumab in patients with moderate/severe active systemic lupus erythematosus: results from EMBLEM, a phase IIb, randomised, double-blind, placebo-controlled, multicentre study. Ann Rheum Dis. 2014;73:183-190.

117. Langford CA, Monach PA, Specks U, et al. An open-label trial of abatacept (CTLA4-IG) in non-severe relapsing granulomatosis with polyangiitis (Wegener's). Ann Rheum Dis. December 9, 2013. [Epub ahead of print.]

118. Cambridge University Hospitals NHS Foundation Trust. Alemtuzumab for ANCA Associated Refractory Vasculitis (ALEVIATE). Available from: http:/www.clinicaltrials.gov/ct2/show/NCT01405807?term= NCT01405807\&rank=1. NLM identifier: NCT01405807. Accessed July 28, 2011
119. Reich K, Langley RG, Papp KA, et al. A 52-week trial comparing briakinumab with methotrexate in patients with psoriasis. $N$ Engl J Med. 2011;365:1586-1596.

120. Leonardi C, Matheson R, Zachariae C, et al. Anti-interleukin-17 monoclonal antibody ixekizumab in chronic plaque psoriasis. $N$ Engl J Med. 2012;366:1190-1199.

121. Papp KA, Leonardi C, Mente A, et al. Brodalumab, an anti-interleukin17-receptor antibody for psoriasis. $N$ Engl J Med. 2012;366: 1181-1189.

122. Karsten CM, Kohl J. The immunoglobulin, IgG Fc receptor and complement triangle in autoimmune diseases. Immunobiology. 2012;217: 1067-1079.

123. Laurino S, Chaudhry A, Booth A, Conte G, Jayne, D. Prospective study of TNFalpha blockade with adalimumab in ANCA-associated systemic vasculitis with renal involvement. Nephrol Dial Transplant. 2010;25:3307-3314.

124. Smith J, McDaid JP, Bhangal G, et al. A spleen tyrosine kinase inhibitor reduces the severity of established glomerulonephritis. J Am Soc Nephrol. 2010;21:231-236.

125. McAdoo SP, Reynolds J, Smith J, et al. [Spleen tyrosine kinase (SYK) inhibition in experimental autoimmune glomerulonephritis (EAG)]. Presse Med. 2013;42:653. French.

126. Weinblatt ME, Kavanaugh A, Genovese MC, et al. An oral spleen tyrosine kinase (Syk) inhibitor for rheumatoid arthritis. N Engl J Med. 2010;363:1303-1312.

127. Lamprecht P, Voswinkel J, Lilienthal T, et al. Effectiveness of TNFalpha blockade with infliximab in refractory Wegener's granulomatosis. Rheumatology (Oxford). 2002;41:1303-1307.

128. Venhoff N, Effelsberg NM, Salzer U, et al. Impact of rituximab on immunoglobulin concentrations and B cell numbers after cyclophosphamide treatment in patients with ANCA-associated vasculitides. PLoS One. 2012;7:e37626.

129. Saravanan V, Kelly C. Drug-related pulmonary problems in patients with rheumatoid arthritis. Rheumatology (Oxford). 2006;45: 787-789

130. Nordic Pharma SAS. Clinical Study Comparing the New Immunosuppressive Drug Gusperimus With the Conventional Treatment in Wegener's Granulomatosis (SPARROW). Available from: http://www.clinicaltrials. gov/ct2/show/NCT01446211?term=NCT01446211\&rank=1. NLM identifier: NCT01446211. Accessed January 19, 2012.

131. University Medical Centre Groningen. Prevention of Relapses in Proteinase 3 (PR3)-Anti-neutrophil Cytoplasmic Antibodies (ANCA)Associated Vasculitis. Available from: http://www.clinicaltrials.gov/ ct2/show/NCT00128895?term=NCT00128895\&rank=1. NLM identifier: NCT00128895. Accessed November 1, 2011.

132. Human Genome Sciences Inc., a GSK Company. Belimumab in Remission of VASculitis (BREVAS). Available from: http://www. clinicaltrials.gov/ct2/show/NCT01663623?term=NCT01663623\&ra nk=1. NLM identifier: NCT01663623. Accessed February 6, 2014.
Therapeutics and Clinical Risk Management

\section{Publish your work in this journal}

Therapeutics and Clinical Risk Management is an international, peerreviewed journal of clinical therapeutics and risk management, focusing on concise rapid reporting of clinical studies in all therapeutic areas, outcomes, safety, and programs for the effective, safe, and sustained use of medicines. This journal is indexed on PubMed Central, CAS,

\section{Dovepress}

EMBase, Scopus and the Elsevier Bibliographic databases. The manuscript management system is completely online and includes a very quick and fair peer-review system, which is all easy to use. Visit http://www.dovepress.com/testimonials.php to read real quotes from published authors. 